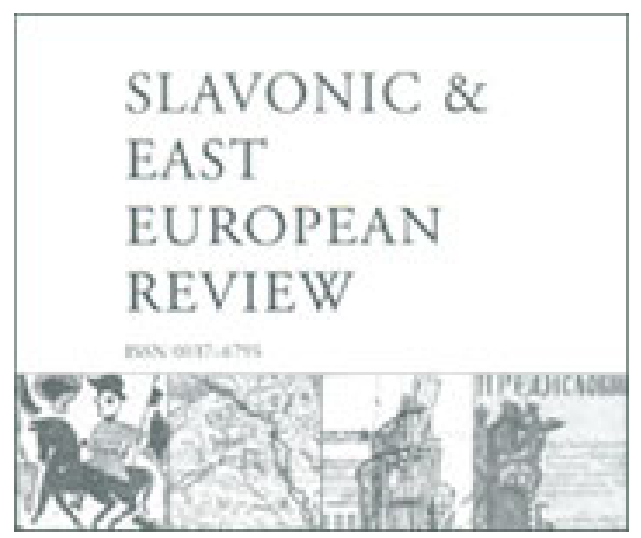

Staging the Holocaust in the Land of Brotherhood and Unity: Holocaust Drama in Socialist Yugoslavia in the 1950s and 1960s

Author(s): Stijn Vervaet

Source: The Slavonic and East European Review, Vol. 92, No. 2 (April 2014), pp. 228-254

Published by: the Modern Humanities Research Association and University College London, School of Slavonic and East European Studies

Stable URL: http://www.jstor.org/stable/10.5699/slaveasteurorev2.92.2.0228

Accessed: $23 / 04 / 2014$ 08:54

Your use of the JSTOR archive indicates your acceptance of the Terms \& Conditions of Use, available at http://www.jstor.org/page/info/about/policies/terms.jsp

JSTOR is a not-for-profit service that helps scholars, researchers, and students discover, use, and build upon a wide range of content in a trusted digital archive. We use information technology and tools to increase productivity and facilitate new forms of scholarship. For more information about JSTOR, please contact support@jstor.org. 


\title{
Staging the Holocaust in the Land of Brotherhood and Unity: Holocaust Drama in Socialist Yugoslavia in the 1950 and 1960 s
}

\author{
STIJN VERVAET
}

THis article considers two theatrical works written by Đorđe Lebović (1928-2004), premiered in Socialist Yugoslavia in the mid-1950s and 1960s: Nebeski odred (The Heavenly Squad, 1957, co-authored with Aleksandar Obrenović) and Viktorija (Viktorija, 1968). Not only was Lebović the first playwright in Socialist Yugoslavia to bring the theme of the Holocaust to a larger audience, but his plays also addressed issues of Holocaust remembrance in a highly original and for that time often provocative manner. Although most of Lebović's plays were met with critical acclaim in Yugoslavia at the time of their staging and some of them were included in anthologies of contemporary Serbian drama as well as referred to in encyclopaedic overviews of modern drama, ${ }^{1}$ his work has so far not attracted a great deal of scholarly interest. I propose to examine how Lebovićs dramas mediated, shaped and circulated narratives of the destruction of European Jews against the background of the specific memory culture of Socialist Yugoslavia. After a brief discussion of Yugoslavia's politics of remembrance of the Second World War and of the

Stijn Vervaet is a postdoctoral research fellow of the Flemish Research Council (FWOVlaanderen) affiliated with the Centre for Literature and Trauma Studies (LITRA) at Ghent University, Belgium.

The author would like to thank Emil Kerenji and Michael Bachmann as well as the two anonymous SEER reviewers for their insightful comments on earlier versions of this article.

1 See, for instance, Slobodan Selenić (ed.), Antologija savremene srpske drame, Belgrade, 1977, pp. 1-112; Vladimir Stamenković (ed.), Savremena drama, Belgrade, 1987, vol. 1, pp. 37-129; Vasa D. Mihailovich, 'Serbian Drama', in Stanley Hochman (ed.), McGraw-Hill Encyclopedia of World Drama, New York, 1984, vol. 1, p. 196, and Ivan Medenica, 'Serbian Drama', in Gabrielle H. Cody and Evert Spinchorn (eds), The Columbia Encyclopedia of Modern Drama, New York, 2007, vol. 2, p. 1210. 
Holocaust, I will take a closer look at both plays. I will not only explore how the plays, as works of fiction, represented the Shoah, but also how they, through their intervention in the public sphere, contributed to the emergence of Holocaust memory in Yugoslavia.

My analysis of Nebeski odred will show how Lebovićs staging of a Sonderkommando not only introduced to the larger public the realities and specificity of the Nazi genocide of the Jews well before the Eichmann trial in 1961-62, but will also reveal how it urged the audience to move away from the black and white categories offered by Socialist Yugoslav memory culture. A closer look at the context of the play's reception will reveal to what extent the ethical and aesthetical problems that preoccupied Lebović differed from the interests of mainstream theatre critics and the dominant politics of remembrance. My close reading of Viktorija, which dramatizes a (fictional) trial of two Nazi camp commanders, traces how Lebović addresses some key issues of testimony, law and justice six years after the Eichmann trial. More specifically, I will analyse how Viktorija, by using the trope of the trial, reveals the linguistic, legal and ethical challenges the judicial system inevitably faces when dealing with Holocaust crimes.

I will argue that Lebovićs plays, through the way in which they staged the Holocaust, deconstruct the perpetrator/victim divide and shed what was at the time an entirely new light on questions of witnessing and empathy, memory and justice; central historical and ethical issues with which any European country was concerned in the aftermath of the Second World War, and which were treated by the Yugoslav authorities as a very sensitive matter. Additionally, I hope to demonstrate that Lebović's plays suggest a complex understanding of traumatic witnessing which in many respects prefigured the insights offered by contemporary scholars of Holocaust and trauma studies. As such, his plays not only significantly differed from the dominant socialist narrative of the Second World War, but also implicitly reveal the blind spot of mainstream socialist memory culture which results from its focus on a heroic narrative of partisan struggle on the one hand, and the sanctification of the victims of fascism on the other - a blind spot which any serious narrative of Holocaust memory inevitably has to confront. At the same time, however, his plays show how within that very frame of Yugoslav socialist culture, an artistic articulation of these issues was possible.

\section{Holocaust Remembrance under the Sign of 'Brotherhood and Unity'}

The way in which the Holocaust was perceived and commemorated in Socialist Yugoslavia in the 1950 a and 1960s differed significantly from the situation in other Communist countries. For a long time, the Holocaust 
remained a taboo topic in some countries, whereas there was even a form of institutionalized antisemitism in others. ${ }^{2}$ Following Tito's break with Stalin and the Cominform in 1948, Yugoslavia developed its own socialist politics based on the ideology of non-alignment with a distinct teleological historical narrative centring on Tito's Communist Partisan movement and its accompanying rhetoric, but with a rather liberal cultural politics. As a consequence, compared to the Soviet Union and other countries of the Eastern Bloc, Yugoslavia never had a strong tradition of Socialist Realism, which means that, with the exception of overt nationalist or antiCommunist rhetoric, writers were relatively free to write about all kinds of topics. The construction of collective memory in Socialist Yugoslavia specifically revolved around the traumas of World War Two and followed the Communist dictum of 'brotherhood and unity' (bratstvo i jedinstvo).

Established on 30 November 1943 during the Second Session of the Anti-Fascist Council for the Liberation of Yugoslavia (Drugo zasjedanje Antifašističkog vijeća narodnog oslobođenja Jugoslavije) in Jajce, ${ }^{3}$ the Yugoslav State Commission for the Investigation of Crimes Perpetrated by the Occupiers and Their Accomplices (Državna komisija za utvrđivanje zločina okupatora i njihovih pomagača) began work the same year and went to great pains to document atrocities committed by the Nazis and their allies against, amongst others, Jews on Yugoslav soil. ${ }^{4}$ However, as Jovan Byford has shown, survivor testimonies and eyewitness accounts collected by the Commission were expected to contribute to the country's 'revolutionary history' and were presented and edited in a way which 'fuse[d] together the dominant ideological motifs of [collective] suffering and resistance'. Most importantly, the collected eyewitness accounts were

2 Timothy Snyder, Bloodlands: Europe between Hitler and Stalin, Philadelphia, PA, 2010, pp. 338-77. For a more nuanced account of the treatment of the Holocaust in Soviet historiography, see Zvi Gitelman, 'Politics and the Historiography of the Holocaust in the Soviet Union', in idem (ed.), Bitter Legacy: Confronting the Holocaust in the USSR, Bloomington and Indianapolis, IN, 1997, pp. 14-42.

3 Leon Geršković (ed.), Dokumenti o razvoju narodne vlasti. Priručnik za izučavanje istorije narodne vlasti na fakultetima, školama i kursevima, Belgrade, 1948, p. 262.

4 Albert Vajs, 'Foreword', in Zdenko Löwenthal (ed.), The Crimes of Fascist Occupants and Their Collaborators Against Jews in Yugoslavia, Belgrade, 1957, p. xiv. Aleksandar Levi specifies that the Regulation of the Work of the State Commission (Pravilnik o radu Državne komisije), which was adopted on 8 May 1944, provided the Commission with a formal legal basis in line with international criminal law. See Aleksandar Levi, 'Krivična dela protiv čovečnosti i međunarodnog prava iz aspekta jugoslovenskog zakonodavstva', Jevrejski almanah, 10-11, 1963/1964, p. 118.

5 Jovan Byford, "'Shortly Afterwards, We Heard the Sound of the Gas Van": Survivor Testimony and the Writing of History in Socialist Yugoslavia', History and Memory, 22, 2010, 1, p. 27. 
regarded solely as 'historical material', not as accounts of individual acts of human suffering. ${ }^{6}$

While the 'official' Yugoslav historiography of the Second World War centred on heroic acts of Communist partisan resistance against the Nazi occupiers, it simultaneously aimed to smooth over the (memory of the) ethnic tensions that had so violently disrupted this multinational country during the war. In essence, this state-supported collective narrative refused to acknowledge the victims of the Second World War in ethnic terms: all victims of the war, regardless of whether they had died as political opponents fighting the Nazis or whether they were killed because of their ethnicity, were subsumed under the larger category of 'victims of fascism' (žrtve fašizma). ${ }^{7}$ However, during the Second World War, more people died as a consequence of inter-ethnic and intra-ethnic violence than at the hands of Nazi Germany and its allies. ${ }^{8}$ Monuments to the fallen heroes of the partisan revolution and to the victims of fascism were erected across the country, ${ }^{9}$ and in addition to novels, partisan films became the most popular medium to disseminate this historical narrative which, like two sides of the same coin, had both a heroic and a martyrological face. ${ }^{10}$ The hero/martyr-dichotomy, however, was not only characteristic of Socialist Yugoslavia. Annette Wieviorka reminds us that, in the immediate post-war years, it was quite common to perceive victims of the Holocaust (and not only of the Second World War in general) either as heroes or as martyrs who died for a certain cause. She refers to the text on the plaque of what was meant to become the first monument to the victims of the Holocaust

6 Ibid

7 Emil Kerenji, Jewish Citizens of Socialist Yugoslavia: Politics of Jewish Identity in a Socialist State, 1944-1974, unpublished PhD thesis, University of Michigan, 2008, pp. 179-85; Milan Koljanin, Nemački logor na beogradskom sajmištu 1941-1944, Belgrade, 1992, p. 267, and Jovan Byford, "'Shortly Afterwards"', p. 24.

${ }_{8}$ See, for this, Bogoljub Kočović, Sahrana jednog mita: žrtve Drugog svetskog rata u Jugoslaviji, Belgrade and Novi Sad, 2005 [1985].

9 For an overview of the state sponsored remembrance of the Second World War in Socialist Yugoslavia in general and the role of monuments in it, see Heike Karge, Steinerne Erinnerung - versteinerte Erinnerung? Kriegsgedenken in Jugoslawien (19471970), Wiesbaden, 2010.

${ }^{10}$ For the hero/martyr dichotomy in Yugoslav socialist prose and poetry about the Second World War, see Enver Kazaz, 'Heroj i žrtva u funkciji pamćenja rata. Književni kanon i ideološki rituali kao temelj nacionalnog pamćenja', in Sulejman Bosto and Tihomir Cipek (eds), Kultura sjećanja: 1945. Povijesni lomovi i svladavanje prošlosti, Zagreb 2005, pp. 141-54. For a nuanced view of the role of popular culture and mass media in the socialist memory politics of the Second World War, see Renata JambrešićKirin, 'The Politics of Memory in Croatian Socialist Culture: Some Remarks', Narodna umjetnost, 41, 2004, 1, pp. 125-43. 
in New York in 1947: 'This is the site for the American memorial to the heroes of the Warsaw Ghetto battle April-May 1943 and to the six million Jews of Europe martyred in the cause of human liberty' (emphasis added - S.V.). ${ }^{11}$

Although Jewish suffering during what would come to be known as the Holocaust was thus officially incorporated into the larger narrative of suffering and resistance of the Yugoslav peoples during the war, Jewish leaders in Yugoslavia, as historian Emil Kerenji emphasizes, 'did not

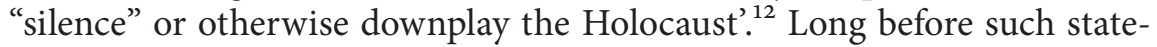
supported commemoration existed in Europe or the USA, they successfully campaigned in 1952 for the erection of five monuments dedicated 'to Jewish victims of fascism in Yugoslavia. ${ }^{13}$ Featuring inscriptions in Hebrew and Jewish motifs, the monuments 'simultaneously conveyed two different cultural contexts - one compatible with the reigning ideological mode of commemorating WWII [...] and one more elusive, and accessible only to those familiar with Jewish culture and tradition.' ${ }^{14}$

By comparison, the first French memorial to the victims of the Holocaust was erected in 1953/56. The first stone was laid in 1953, and the monument was inaugurated three years later. Initially called Tomb of the Unknown Jewish Martyr, in 1974 its name was changed into Memorial to the Unknown Jewish Martyr. ${ }^{15}$ Wieviorka mistakenly notes that 'Until the early 196os, it was the only public memorial [to the victims of the Holocaust] located in a public space in the world'. ${ }^{16}$ The only memorial that preceded both the 1952 monuments in Yugoslavia and the one in Paris would be Nathan Rapaport's Warsaw Ghetto Monument, dedicated to the memory of the Warsaw Uprising (more specifically, 'To the Jewish People - Its Heroes and Its Martyrs', as it is inscribed on the monument in Polish, Yiddish and Hebrew), which was unveiled on 19 April $1948 .{ }^{17}$

Not unlike in the USA, Israel and much of Western Europe ${ }^{18}$ the Eichmann trial of 1961-62 also seems to have been a watershed moment

${ }^{11}$ Annette Wieviorka, The Era of the Witness, Ithaca, NY and London, 2006, pp. 47-48.

${ }^{12}$ Kerenji, Jewish Citizens, pp. 192-93.

13 Ibid.

${ }^{14}$ Ibid., p. 213.

15 Annette Wieviorka, 'Un lieu de Mémoire et d'Histoire: le Mémorial du martyr juif inconnu', in Foulek Ringelblum (ed.), Les juifs entre la mémoire et l'oubli, Brussels, 1987, pp. 107-32.

${ }^{16}$ Wieviorka, The Era of the Witness, p. 51.

17 For the 'biography' of the Rapaport monument, see James E. Young, The Texture of Memory: Holocaust Memorials and Meaning, New Haven, CT and London, 1993, pp. $155-84$.

${ }^{18}$ Wieviorka, The Era of the Witness, p. 56 ff.; David Cesarani (ed.), After Eichmann: Collective Memory and the Holocaust since 1961, London and New York, 2005. 
in Yugoslavia in that it introduced the specificity and the magnitude of the Nazi genocide of European Jews to the general public. ${ }^{19}$ Nevertheless, it would be an exaggeration to claim that the Holocaust remained entirely unacknowledged or was even silenced in the years preceding the trial, as has already been demonstrated by Kerenji's assessment of the small-scale commemorations and monuments from the early 1950s. In my subsequent discussion of the first Yugoslav Holocaust play and its reception, I hope to demonstrate that the case of early Yugoslav Holocaust commemoration was actually more complex, both regarding the appropriation of Jewish suffering by the Yugoslav master narrative and concerning the pre-/postEichmann trial dichotomy.

\section{'The Heavenly Squad': The Play and the Debate}

The first theatre play on the Holocaust to be published and performed in Yugoslavia was entitled Nebeski odred (The Heavenly Squad) and was written by two young playwrights: Aleksandar Obrenović and Đorđe Lebović. The latter was deported to Auschwitz in 1944 at the age of fifteen. The play is set inside Auschwitz-Birkenau concentration camp and tells the story of the Himmelkommando, as the Special Squad (Sonderkommando) in the play is ironically dubbed by its members. They are a group of seven inmates who had been forced to choose between being killed immediately or accepting to assist the SS in the crematoria for three months, after which period they would be killed by the SS and their corpses burned by their replacements. At the time when Lebović and Obrenović wrote Nebeski odred, published eyewitness accounts or interviews with surviving members of the Sonderkommandos were not yet available. The Nazis had proclaimed the members of the Sonderkommando as Geheimnisträger (Bearers of Secrets) and did their best to keep them separated from the other prisoners; most prisoners had heard only rumours about them. ${ }^{20}$ During his last months in Auschwitz, however, Lebović was assigned to a group of inmates tasked with dismantling the crematoria, and during these works he met a member of the last Sonderkommando, a Polish Jew who told him his story. ${ }^{21}$

Lebovićs encounter with the Polish inmate is echoed in the prologue to the play where an anonymous first person narrator and Auschwitz survivor describes his meeting with a Sonderkommando prisoner who tells him about the life he and the other members of the Sonderkommando prisoners

19 Kerenji, Jewish Citizens, p. $187 \mathrm{ff}$.

${ }^{20}$ Gideon Greif, We Wept Without Tears, New Haven, CT and London, 2005, pp. 4, 11.

${ }^{21}$ Zlata Lebović, Dijalog o zlu i dobru, Novi Sad, 2011, p. 59. 
led. ${ }^{22}$ Building directly upon Lebović's own experiences/autobiography, the play makes an implicit but clear claim to truthfulness. What is more, the narrator, who introduces himself with the words 'I am A-12750', has the same number tattooed on his arm as Đorđe Lebović. ${ }^{23}$ Presenting himself as a second-degree witness, the narrator says:

I will do my best to bring to life the stories of my friend 33142. Maybe I'll change or skip something in my story, the characters I'll mention probably did not exist in reality, but everything that surrounded them did. ${ }^{24}$

After a brief introduction of the main characters, the narrator leaves the scene and no longer participates in the piece.

Rather than explicitly showing on stage the horrifying tasks the Sonderkommando had to perform, the play itself is set in the closed space of the barracks in which the inmates live. The characters represent different 'types' of inmates: the 'Muselmann', the kapo, the 'prominent', the 'organizer', thus introducing the audience to the concentrationary universe of the Nazi extermination camps. Given that they come from all over Europe, they all have a different background: the secular Jew and political prisoner from Paris, the orthodox Jew axis clock-maker, the German small criminal, the Polish intellectual, the Italian clerk and POW, the Greek sculptor, the Serbian introvert and an old Russian POW who gives them instructions and appoints one of them as kapo. ${ }^{25}$ They call each other by various nicknames, one of them even only by his number. Their dialogues, discussions and quarrels not only evoke the horrible reality of the crematoria and the daily life of the Sonderkommando, but also reveal the moral dilemmas and severe psychological pressure with which the Sonderkommando prisoners had to deal. The concealed space of the barrack mirrors the hopelessness of the situation in which they are caught: there is no way out. When the old Russian tells them what tasks are waiting for them, they are in total disbelief. Once they fully realize what they have to do, they first try to do the 'least compromising' jobs - preferring the

\footnotetext{
${ }^{22}$ Đorđe Lebović and Aleksandar Obrenović, Nebeski odred, Novi Sad, 1959, pp. 7-8.

${ }^{23}$ Lebović, in an interview conducted by Miloš Jevtić, broadcast on Radio Belgrade's Second Programme on 14 and 21 March 1986.

${ }^{24}$ Lebović and Obrenović, Nebeski odred, p. 9.

${ }^{25}$ Such a multi-religious cast seems rather to mirror the population structure of the concentration camp as a whole than that of the Sonderkommando: Greif reminds us that almost all members of the Sonderkommando were Jews, except for the first group, which was not yet called by that name. See Greif, We Wept Without Tears, pp. 2-3, 11.
} 
'ovens' to the 'bathroom'26 - and then to forget, or at least pretend not to think of, the 'work' they are doing - for example, the clockmaker does this by obsessively repairing a clock and responding to the horrors of the camp by quoting from the Bible, the sculptor by collecting gold teeth from which he intends to make a sculpture of Leda, the intellectual by drawing a map of the crematoria and keeping a record of the transports that arrive every day, and the thief by eating and drinking the extra food they collect from the murdered prisoners. One by one they collapse, the 'Muselmann' being the first. They consider escaping, but for various reasons cannot reach a consensus, partly out of fear of being caught or drowning in the moors next to Auschwitz, partly because they are afraid that their kapo will discover their plans or that the old Russian will betray them. One of them, Serbe, the prisoner known as Nr. 58964, even maintains that it makes no sense to try to escape, arguing that, even if they would manage to do so, they would be haunted their whole lives by the memories of the 'work' they had done. He subsequently throws himself on the electrified fence. When their final five days arrive, the old Russian, contrary to his promise, refuses to help them escape, and they strangle him. The kapo (the Greek sculptor) attacks an SS officer with a knife and is killed. Suspecting that the 'Green' (the criminal) has betrayed them, the inmates understand that there is no possible exit, and the play ends with the clock counting down their final minutes.

On the one hand, The Heavenly Squad functions as a traditional realist play which introduces the audience to the reality of the concentration camp and the hell of the Sonderkommando. ${ }^{27}$ On the other hand, the portrayal of the desperate position of the Sonderkommando, underscored by the open ending of the play, is combined with dark humour and at times grotesque conversations between the characters which make it difficult, if not impossible, for the audience to identify with the characters on stage or to reject them unequivocally as 'bad guys. ${ }^{28}$ Instead of judging them as mere collaborators or murderers - which was, as Gideon Greif reminds us, the most common attitude to the members of the Sonderkommando

${ }^{26}$ The gas chambers were disguised as bathrooms. In The Heavenly Squad (p. 21) it is suggested that the members of the Sonderkommando threw Zyklon-B into the gas chambers. However, this seems to contradict historical evidence: Greif points out that only German Sanitärer (medical orderlies) poured Zyklon B. See We Wept Without Tears, p. 15.

27 This leads Slobodan Selenić to claim that The Heavenly Squad was actually 'the first Serbian realist theatre piece after the liberation'. Selenić, 'Predgovor', in idem (ed.), Antologija, p. xxii.

${ }^{28}$ The grotesque character of the play was also noticed by Vladimir Stamenković in his introduction to Savremena drama, vol. 1, pp. 16-17. 
in the immediate post-war years ${ }^{29}$ - the piece shows that the situation in which its characters are trapped is so extreme that it is impossible to talk about 'normal human behaviour' or 'normal moral decisions', let alone to judge them according to these categories. ${ }^{30}$

Much like Primo Levi, Lebović is interested in 'the grey zone': the case of the Sonderkommando becomes an extreme example of impotentia judicandi - a matter in which it is impossible to judge. Levi coined the phrase 'the grey zone' to refer to an area of moral ambiguity and complicity to which our conventional norms and categories of good and evil cannot be applied. Noting the human tendency to simplify history, Levi writes that 'the network of human relationships inside the Lagers was not simple: it could not be reduced to the two blocs of victims and persecutors ${ }^{3}{ }^{31}$ Moreover, the division into 'simple prisoners' and 'privileged ones', as well as the way in which the Nazi camp authorities used privileges to turn victims into collaborators created 'a gray zone, poorly defined, where the two camps of masters and servants both diverge and converge. This gray zone possesses an incredibly complicated internal structure and contains within itself enough to confuse our need to judge..$^{2}$ The strategy which the Nazis used to bind their victims is one of coerced complicity: 'the best way to bind them is to burden them with guilt, cover them with blood, compromise them as much as possible, thus establishing a bond of complicity so they can no longer turn back. ${ }^{33}$ One of the most compelling examples of the grey zone Levi describes - he calls it a limit case of collaboration, emphasizing that he 'hesitates to speak of privilege' - is indeed the case of the members of the Sonderkommando, 'the crematorium ravens', as he calls them. He proposes that we 'meditate on [their] story [...] with pity and rigour', all the while insisting 'that judgment of them be suspended' ${ }^{34}$ Lebovićs effort to draw attention to the Sonderkommando's position of coerced complicity, however, was not appreciated, or not understood, by many of the leading theatre managers and critics of his time.

First published in the journal Pozorišni život (Theatre Life) in 1956, The Heavenly Squad was rejected by the three main theatres in Belgrade.

${ }^{29}$ Greif, We Wept Without Tears, pp. 71-74.

30 As Lebović himself said in an interview with Miloš Jevtić: 'it is impossible to establish universally applicable standards by which we could today make moral claims about the behaviour of people [interned] in Auschwitz.' Radio Belgrade, 2nd Programme, 14 March 1986.

31 Primo Levi, The Drowned and the Saved, New York, 1989, p. 37.

${ }^{32}$ Ibid., p. 42.

33 Ibid., p. 43.

34 Ibid., pp. 50-60. 
Specifically, the manager of the Beogradsko dramsko pozorište (Belgrade Drama Theatre), Predrag Dinulović, wanted to stage the play, but he could not overcome the reticence of his collaborators; in the Jugoslovensko dramsko pozorište (Yugoslav Drama Theatre), Miroslav Belović and Tomislav Tanhofer wanted to stage it, and managed to convince the entire cast, but not the manager, Velibor Gligorić. Hugo Klajn's attempts at putting it on the programme of the Narodno pozorište (National Theatre in Belgrade) were rendered fruitless by the theatre's manager, Milan Bogdanović, who saw the play as an example of how 'two young decadents gave free rein to their pathological condition.'35 However, the play premièred the same year in a small provincial theatre, in Priština (Kosovo), directed by Slobodan Popić, ${ }^{36}$ and was also staged in March 1957 by Dimitrije Đurković in the Srpsko narodno pozorište (Serbian National Theatre) in Novi Sad, ${ }^{37}$ but it did not attract any significant critical attention. This changed, however, after the play was staged (also by Đurković) in May 1957 on the Sterijino pozorje (Sterija's Scene) in Novi Sad. This was the first edition of what was to become one of the leading theatre festivals of the country, and Lebović's and Obrenovićs play was awarded the Sterijina nagrada za najbolju savremenu domaću dramu (Sterija Award for the Best Contemporary National Drama). In June of the same year, The Heavenly Squad was staged by Hugo Klajn in the vanguard theatre, Atelje 212 (Atelier 212) in Belgrade, ${ }^{38}$ after which it was performed in cities all over Yugoslavia, from Titovo Užice, Kruševac, Leskovac, Bitola and Zenica in 1957 to Zagreb in 1958 and Split in $1960 .{ }^{39}$ After its success on the Sterija Scene, The Heavenly Squad was not only reviewed in the specialized literary and theatre journals Književne novine (Literary Newspaper), Letopis Matice srpske (The Matica srpska Chronicle), Naša scena (Our Scene), Republika (Republic) and Teatar (Theatre), ${ }^{40}$ but also attracted the

\footnotetext{
${ }^{35}$ Lebović, in an interview conducted by Miloš Jevtić, Radio Belgrade, 2nd Programme, 21 March 1986.

${ }^{36}$ Bora Slepčević, 'Priština: Prvo izvođenje domaće drama Nebeski odred', Naša scena, $11,1957,120$, p. 5.

37 Slobodan Selenić, “Nebeski odred” Lebovića i Obrenovića na sceni Srpskog narodnog pozorišta u Novom Sadu', Borba, 28 March 1957, p. 5.

${ }^{38}$ Slobodan Selenić, “"Nebeski odred” na sceni Ateljea 212', Borba, 16 June 1957, p. 6.

39 Lebović and Obrenović, Nebeski odred, p. 89; Zvonimir Berković, 'Uz sinoćnu izvedbu drame "Nebeski odred”. Uspjela predstava', Večernji vjesnik, 12 January 1958, p. 3; Č. Ć., 'Stravičnost i optužba jednog svjedočanstva', Slobodna Dalmacija, 7 May 1960, p. 3.

${ }^{40}$ Oliver Novaković, 'Novosadska premijera. Nebeski odred. Đorđe Lebovići Aleksandar Obrenović', Naša scena, 11, 1957, 123, p. 3; Oliver Novaković, 'Druge jugoslovenske pozorišne igre', Naša scena, 11, 1957, pp. 126-27, p. 5; Vladimir Stamenković, 'Lebović i Obrenović: Nebeski odred', Književne novine, 19 May 1957, p. 7; Dušan Popović, 'Lebović - Obrenović:
} 
attention of leading newspapers and weeklies, including Politika (Politics), Borba (Combat) and NIN (Nedeljne informativne novine - Weekly Informative Newspaper). ${ }^{41}$ However, the award-winning play was not unanimously praised. In what follows, I will zoom in on the debate which played out on the pages of the leading weekly journal, NIN, and examine why the award-winning play stirred up such a controversy amongst critics.

Following Borislav Mihajlovićs positive review of the play, who had called it 'the event of Sterija's Scene in 1957 ', ${ }^{42}$ Bora Glišić, another prominent theatre critic of the time, published a devastating review, calling it an example of 'a naturalistic, nihilist vulgarizing materialist style which had never really been able to survive in serious theatre and which had already long been superseded. ${ }^{43} \mathrm{He}$ emphasized that, although at the opening night in Novi Sad and in Belgrade the audience differed in opinion as to the veracity of the piece, everyone left the theatre in a gloomy mood, overwhelmed by its dark topic. According to Glišić, some people accepted the play as 'a terrible truth from which there is no escape', while others 'considered that there is no truth in the piece, exactly because everything is so terrible and because it is on the border of totalitarian immoralization [imoralizacija] and dehumanization'. ${ }^{44}$ Pointing out that the two playwrights had 'chosen not only to put on stage one of most horrible topics, the killings by the Nazis in concentration camps [...], but even to let the inmates perform the most horrible task, which, according to this drama, even the Nazis were not prepared to do - the gassing and burning of their own fellow prisoners', he accused them of 'not [being] moderate enough' in their display of the horror, something for which he found no better explanation than to suggest that 'all young writers love the effect of astonishment ${ }^{35}$ - thus insinuating that the authors had invented a significant amount of the horrors. In the final paragraph, Glišić explains the title of his review ('O wonderful scorpion!'), referring to the scorpion as an animal that allegedly kills itself when it is captured and sees no way to escape. Thus, Glišić seems to suggest that even a scorpion would be more human than the members of the Sonderkommando in The Heavenly Squad.

Nebeski odred', Letopis Matice srpske, 133, book 379, 1957, 5, pp. 502-07; Vlado Mađarević,

“"Nebeski odred” Lebovića i Obrenovića', Teatar, 4, 1958, 1-2, pp. 42-44, Vlado Mađarević,

“"Nebeski odred” Lebovića i Obrenovića. Atelje 212', Republika, 14, 1958, 1, p. 25.

${ }^{41}$ M. Čolić, 'Đ. Lebović i A. Obrenović: Nebeski odred', Politika, 18 May 1957, p. 8; Slobodan Selenić, 'Afirmacija domaće drame', Borba, 21 May 1957, p. 5.

${ }^{42}$ Borislav Mihajlović, 'Događaj Sterijinog pozorja 1957', NIN, no. 335, 2 June 1957, p. 8.

43 Bora Glišić, 'Divni škorpione!', NIN, no. 338, 23 June 1957, p. 9.

${ }^{44}$ Ibid.

45 Ibid. 
Accusing them of 'outdated naturalism, horrific dehumanization', 'inverting victim and perpetrator', 'feeling sympathy with the perpetrators' and underlining that 'factography cannot contain the whole sense of human truth', Glišić's critique essentially boiled down to the argument that it is impossible to stage a tragedy without catharsis; in other words, that Lebović and Obrenović had sinned against the supreme law of Aristotelian drama. The gloomy mood of the audience was, according to Glišić, caused by the fact that the piece

deals with the tragic motif not only in an unspiritual but also in an animalistic way: there is neither heroism, nor ideology, nor human faith, nor dreaming, nor redemptive illusions, nor a commemoration of the millions that died, nor any memories [of them], nor any nobleness of mind. Not even a grotesque. The whole of human life is reduced to biology and physiological functions. Alas, if that is all! In what should one believe then? And so - instead of the good, corny catharsis [...], the audience is left with the only option of collectively visiting a psychoanalyst. All this cannot be human truth! ${ }^{46}$

Glišićs review not only shows that, some five to six years before the Eichmann trial, leading critics of the time were not only badly informed with regards to the hard facts of the Nazi genocide of the Jews, but they were also not ready to adapt to realist stagings of the Nazi extermination camps - stagings that did not match their views on what is 'human' or 'moral', and did not fulfil their expectations of a heroic or tragic emplotment. In addition to this, Glišićs criticism of the play echoes the prevailing monumental memory culture of Socialist Yugoslavia. Expressing his astonishment at the idea that 'the best amongst those who in the name of humanity rose against Nazism (otherwise they would not have been in the camp), to prolong their lives with a mere three months, agree to kill unfortunate people so close to themselves, to take upon them a role which, according to this drama, even the Gestapo did not want to', ${ }^{47}$ Glišić seems to echo the belief that only political prisoners were deported to the concentration camps and that, by virtue of their anti-fascist conviction, all prisoners automatically behaved as heroes with unfailing ethical standards. Thus, apart from the perceived lack of catharsis, Glišić seems to have been disturbed by the identity of the inmates and by the way in which Lebovic showed that, in the case of the Sonderkommando, a clear-cut distinction between (anti-fascist) victim and (Nazi) perpetrator becomes untenable.

\footnotetext{
${ }^{46}$ Ibid.

47 Ibid.
} 
Dušan Matić and Ivan Ivanji, two other acclaimed writers and literary critics, joined in the discussion, countering Glišićs interpretation of the piece, each with different arguments. ${ }^{48}$ Not surprisingly, the fiercest and for my point most interesting - reaction came from Ivan Ivanji, who had himself survived Auschwitz and Buchenwald and published They Didn't Kill Man (Čoveka nisu ubili) in 1954, a novel based on his camp experiences. Enraged by Glišićs unwillingness to accept that the world staged by Lebović and Obrenović was based on historical truth, Ivanji wrote that he could not believe that

twenty years after the concentration camps had opened their gates, a well-meaning critic who calls upon Aristotle [...] had not found any collection of documents, any book from the Nuremberg trials, any work by an eyewitness without literary pretensions in which he could have confidence and come to the conclusion that this 'dramatic moment', this 'tragic culmination' was not invented by Lebović and Obrenović but by Hitler, Himmler and their collaborators. [...] The most horrifying experiment ever performed in history, and which was called Oswiencim [sic] or Auschwitz, proved that prisoners agreed to kill their brothers only to prolong their lives by a few months. It showed that it is possible to kill the human in a man, and that a man is not always a scorpion that will kill itself when it doesn't see an exit. ${ }^{49}$

Secondly, Ivanji tackled Glišić's expectations of the drama as a piece of art: 'I don't know whether this is art according to Aristotle, but if this isn't, then I am not for art but for the truth. ${ }^{50}$ Finally, he stressed that 'there should be created an audience that does not only want to sleep quietly on the wellprepared cushions of heroism, the virtue of a false, petty bourgeois morals and ethics grown from Christian roots which the merciless wind of the oth century cannot bear', adding that it should be possible, in a Brechtian way, to tell the truth and fight for the dignity of man on the stage. ${ }^{51}$

Beneath Glišićs incomprehension of The Heavenly Squad and the entire polemic surrounding the play, I believe, lie two different understandings of witnessing. As Giorgio Agamben reminds us, Latin has two words for witness: 'The first word, testis, signifies the person who, in a trial or lawsuit

${ }^{48}$ Dušan Matić: 'U pitanju je jedan užasni vide tragedije modernog čoveka', Ivan Ivanji, 'Plemenito bežanje od istine', NIN, no. 339, 30 June 1957, p. 8. (Not unlike Borislav Mihajlović, Dušan Matić was a member of the jury that had awarded the Sterija Prize to Lebović's and Obrenović's piece.)

${ }^{49}$ Ivanji, 'Plemenito bežanje od istine', p. 8.

${ }^{50}$ Ibid.

51 Ibid. 
between two rival parties, is in the position of a third party $\left({ }^{*}\right.$ terstis). ${ }^{52}$ Yugoslav memory politics, as we have seen, epitomizes this understanding of a witness, because it saw eyewitness accounts of war atrocities merely as historical material which illustrated the crimes of the Nazis and proved the righteousness of the socialist revolution, and could potentially be used in a trial against war criminals.

'The second word for witness, superstes', according to Agamben, 'designates a person who has lived through something, who has experienced an event from beginning to end and can therefore bear witness to it. ${ }^{53}$ It is in this sense of witness that Lebović's writings acquire their full weight. In a series of conversations written down and published posthumously by his wife, Lebović commented:

writing is my fate. [...] For me, forgetting everything I went through is simply impossible. [...] Writing is the need to justify the sin of my own existence [...] Fate has decided I be a witness against my epoch. ${ }^{54}$

Furthermore, he added that 'writing about Auschwitz was not merely a therapy for [him], nor was it just a theme on which [he] wrote', and that 'the camps [were] before all [his] experience. ${ }^{35}$

Driven by the impetus to witness, Lebović's Heavenly Squad could not be embedded in the Yugoslav grand narrative of heroic partisan struggle, martyrdom for the revolution and brotherhood and unity. Moreover, to a certain extent it even disrupted this narrative - not so much by stressing the Holocaust as a specific Jewish trauma, but on another level, by emphasizing the position of the witness as a survivor. The discrepancy between these two notions of witnessing might, however, also shed some additional light on Glišić's reference to Aristotle and his understanding of catharsis, as well as why this point was of such importance for Ivanji. More specifically, Glišić's reference to Aristotle might have unexpected implications which, once again, can be related to the politics of remembrance. In Aristotle's view, catharsis functions as a 'disciplining of the social body', as one of the 'identifying systems that prevent social disruption and disorder' and which, as such, makes tragedy 'useful [...], precisely because it displaces unruly emotion into the realm of art in order to maintain order in the state.56

52 Giorgio Agamben, Remnants of Auschwitz, New York, 2002, p. 17.

53 Ibid.

${ }^{54}$ Zlata Lebović, Dijalog o zlu i dobru, p. 30.

55 Ibid., p. 32.

${ }^{56}$ Page duBois, 'Toppling the Hero: Polyphony in the Tragic City', New Literary 
Lebovićs first Holocaust piece not only shows that, as in many other Holocaust plays, the viewer's, reader's, or critic's 'desire for artistic or ethical closure [is] entirely beside the point ${ }^{57}$ because the case of the Sonderkommando as such makes it impossible to imagine any cathartic emplotment. It also reveals how this very impossibility of catharsis unavoidably frustrates any attempt at appropriating the piece for a politics of remembrance resting (solely) on a Manichean interpretation of the (traumatic) past that leaves no alternative to heroic resistance on the one, and the sanctification of suffering on the other.

\section{'Viktorija': Justice after Auschwitz?}

After the Eichmann trial, Lebovićs dramas also continued to play an important role in the raising of Holocaust awareness in Yugoslavia. For his second Holocaust play, Halelujah (1964), written and staged during the Socialist period, Lebović was again awarded the Sterija Award for the Best Contemporary National Drama at the Sterija Theatre Festival. The play dealt with the traumatized feelings of camp survivors and their desire to establish a 'normal' life after the war and to finally be treated as human beings. Viktorija (1968), his third Holocaust play, will be discussed in more detail below. In 1985, Lebovićs radio drama, Traganje po pepelu (Searching the Ashes), directed by Bodo Marković, obtained the Prix Italia, the National Italian Press Association Prize for Documentaries. The drama was based on the diaries of members of the Sonderkommando who had buried their writings in Auschwitz in metal jars, which were discovered in the 1960s. Lebović's last play, Vojnik i lutka (The Soldier and the Puppet), which he wrote in 1998 during his stay in Israel, was commissioned by the Beit Lessin theatre in Tel Aviv, but was never performed there because the theatre's artistic director insisted on making some changes in the text with to which Lebović could not agree. Set in the 1970s, the play deals with themes that are highly relevant to the post-war context of the former Yugoslavia: it tells the story of female camp survivors who were forced to work as prostitutes in a brothel for SS officers, and who, after years of silence, have the chance to be witnesses at a trial against the commander of the brothel, but are put under pressure by the commander himself, by (some) members of their families and by fellow inmates who do not want

History, 35, 2004, 1 (Rethinking Tragedy), p. 68. For a similar interpretation of Aristotle's understanding of catharsis, see Christoph Menke, 'Der ästhetische Blick: Affekt und Gewalt, Lust und Katharsis', in Gertrude Koch (ed.), Auge und Affekt. Wahrnehmung und Interaktion, Frankfurt am Main, 1995, pp. 230-46, esp. 237-45.

${ }^{57}$ Robert Skloot, 'Holocaust Theatre and the Problem of Justice', in Claude Schumacher (ed.), Staging the Holocaust: The Shoah in Drama and Performance, Cambridge, 1998, p. 21. 
the story to get out. The text of the play has since been published in Serbia, but has not yet been performed there.

Shifting the focus from the reality of the extermination camps to the post-war Nazi war-criminal trials, Viktorija investigates the (im)possibility of judgement in a more literal or direct sense, namely in the legal context of the court. We could, thus, say that, next to the witness as third party (te(r)stis) and the witness as survivor (superstes), Lebović here introduces a third dimension to witnessing: the witness as judge (arbiter). As Michael Bachmann has observed, Agamben did not include the Latin word arbiter in his discussion of the etymology of our modern concept of the witness. Nevertheless, its roots are, as Emile Benvéniste has pointed out, etymologically related both to our modern concept of the witness and to that of the judge, the latter denotation becoming its dominant meaning. ${ }^{58}$ Lebovićs decision to stage a trial might appear as rather unsurprising, not only because of the fact that many of the trials against Nazi commanders were still relatively recent in people's memories, but also because a trial in court quite naturally triggers associations with theatre.

Viktorija fictionalizes certain elements of (at least) two historical trials: the 1947 Krakow Auschwitz Trial and the Frankfurt Auschwitz Trials (196365). In a series of conversations with his wife, Lebović briefly mentions that he drew upon the stories of survivors of the Auschwitz-committee who had testified in trials against Nazi perpetrators, and that he himself had been a witness, but does not specify in which trials. ${ }^{59}$ Staging a (fictional) trial against former Nazi camp commanders at Auschwitz, Viktorija not only turns our attention to the mind of the Nazi perpetrators but also questions the possibility of post-war justice within the existing legal framework, the value of survivor testimony in court and the moral as well as psychological difficulties faced by Holocaust survivors acting as witnesses in such trials. In what follows, I will argue that the play, in the way that it represents the legal, linguistic and ethical issues that arise during the trials against Nazi camp commanders, lays bare the limitations (not to say the sheer impotence) of the judicial system when confronted with the challenge of determining guilt and complicity in Holocaust crimes. Finally, I will demonstrate that the piece reveals the ambiguous role and shortcomings of the law as an instrument to 'translate traumatic memory into a legal idiom ${ }^{60}$ and to establish historical truth.

58 Michael Bachmann, Der abwesende Zeuge, Tübingen 2010, p. 73, and Emile Benvéniste, Le vocabulaire des institutions indo-européennes, Paris, 1969, vol. 2, pp. 119-22.

59 Zlata Lebović, Dijalog o zlu i dobru, p. 235.

${ }^{60}$ Shoshana Felman, The Juridical Unconscious: Trials and Traumas in the Twentieth 
The plot of Viktorija is rather complex because the play alternately stages scenes of the two trials and their subsequent court reconstructions, as well as the intermingling and conversations of the protagonists outside the court. The play is set in Auschwitz-Birkenau, where former inmates of the extermination camp meet twenty years after the war as witnesses in the trial against two commanders of the camp, Erih Ferdinand Musfeld and Ludvik Klaus Pendel. Musfeld is accused of having 'unlawfully' (i.e. without an order from above) killed a member of the Sonderkommando whom he suspected of being involved in the preparation of an uprising, whereas Pendel stands accused of letting his subordinates commit a massacre of female inmates in the camp brothel. Musfeld, ${ }^{61}$ who admits to having killed the man without the knowledge of his superiors but claims to have done so in order to prevent his whole unit from being killed, which would have inevitably happened should the camp authorities have found out about the Sonderkommando's attempt at rebellion, is convicted. Pendel, who denies there had been a massacre and instead claims to have suppressed an uprising in the camp brothel according to the military regulations in force at the time, is acquitted. Although in both cases the verdict is reached after extensive hearings of the survivors, the viewer/ reader is left with a profound feeling of injustice.

As the trial proceeds, it not only becomes clear that the circumstances in the camp were much more complex than the accusations against Musfeld and Pendel seem to imply, but also that the witnesses/survivors themselves are profoundly divided over what happened at the time. This is not so much due to the intrinsic unreliability of human memory as it is to the reality of the 'concentrationary universe' on which clear-cut notions of guilt and innocence, complicity and resistance, morality and immorality seem to lose their grip and which, hence, complicate or even resist the possibility of recalling and narrating the events in the straightforward and coherent way required by a trial. In order to determine who is guilty, the

Century, Cambridge, MA, 2002, p. 164.

${ }^{61}$ The name of this character clearly alludes to Erich Mußfeldt, who in May 1944 was the supervising officer of the Jewish Sonderkommando at crematoria II and III in Auschwitz II-Birkenau. Mußfeldt, who served at Majdanek, Auschwitz and Flossenbürg, was notorious for his cruelty, amongst other things for carrying out many executions of camp inmates personally, by a shot to the back of their head. See the memoirs of Miklós Nyiszli, U službi doktora Mengelea [Hung. or. Orvos voltam Auschwitzban, lit. I Was a Doctor in Auschwitz], Zagreb 1981, pp. 47, 64-65. In 1947, he was tried in Kraków and sentenced to death by hanging. See Ernst Klee, Das Personenlexikon zum Dritten Reich. Wer war was vor und nach 1945, Frankfurt am Main, 2003, p. 425. Lebović himself had a brief encounter with Mußfeldt at Auschwitz immediately after crematorium III had been blown up in January 1945, when the Red Army was already approaching the camp. See Zlata Lebović, Dijalog o zlu i dobru, pp. 63-64. 
court, however, needs to establish what happened and to organize these hard facts in a logical and linear narrative. What the trial aims to do is provide a form of closure or, in other words, catharsis, something which Lebović once again shows to be deeply problematic. To be sure, Lebovićs play never questions the need for the perpetrators of Holocaust crimes to be brought to justice. What it does question, however, is the possibility of 'the conventional idiom of criminal law [to] accommodate the extreme evil of genocide ${ }^{62}$ and the validity of the court's efforts to provide closure for the traumatic memories of the survivors.

A first issue Viktorija raises and which can be related directly to the prevailing memory culture of Socialist Yugoslavia ${ }^{63}$ and its approach to survivor testimony is the discrepancy between the often assumed idea of heroic resistance among non-survivor audiences versus what Lawrence Langer calls 'the unheroic memory' of survivors of the concentration camps. Based on an examination of the testimonies of concentration camp survivors, Langer concludes that, because the camp inmate

was never in control of the consequences [of his or her actions, for example, of an act of sabotage or an attempt to escape], the ensuing drama resists all efforts at interpretation using traditional moral expectations. [...] Even when resistance and sabotage occurred, they could not be acclaimed, and rarely were, by the actors themselves, as gestures of heroic defiance. ${ }^{64}$

Viktorija makes this even more explicit by a further twist in the plot, introducing the trope of the uprising of the victims against their perpetrators. While an uprising is usually interpreted as an act of heroic resistance, the play shows these uprisings (and the post-war accounts thereof) to be far more ambiguous, making it impossible to judge the behaviour of the actors involved by conventional moral standards.

In the case against Musfeld, the story of the thwarted uprising of the Sonderkommando is complicated by an intrigue that is still unresolved when the trial starts: one of the members of the Sonderkommando must have told Musfeld that a rebellion was being prepared, but none of the

\footnotetext{
${ }^{62}$ Lawrence Douglas, 'The Memory of Judgment: The Law, the Holocaust and Denial', History \& Memory, 7, 1996, 2, p. 101.

${ }_{63}$ Socialist Yugoslavia was not an exception in this respect. On the pervasive notion of camp survivors as heroes in 1960 s France, see Samuel Moyn, A Holocaust Controversy. For the way in which the first drafts of the Yad Vashem memorial betray 'an absolute symmetry between Holocaust and heroism', see Tom Segev, The Seventh Million: The Israelis and the Holocaust, trans. Haim Watzman, New York, 200o, pp. 421-45 (p. 430).

${ }^{64}$ Lawrence Langer, Holocaust Testimonies: The Ruins of Memory, New Haven, CT and London, 1991, p. 183.
} 
surviving members knows who, except for Musfeld and the betrayer himself. In addition to this, during the trial reconstructions, another drama is revealed (or, rather, re-enacted) which sheds an entirely different light on the notion of (heroic) resistance: if they want to save Gošer, the leader of the resistance movement who had been 'selected' for the gas chambers because his right arm is missing, the members of the resistance have to replace his name on the list with one of their own. One of the clerks is found willing to replace Gošer's number with that of someone else, but insists that they 'choose' a number themselves, one which of course needs to belong to an actual inmate:

Gošer: The Schreiber [clerk] has agreed. He will replace me [with someone else].

Jup: How?

Gošer: He will wipe out my number from the list and put in another one.

Edek: Good job, Gošer.

Gošer: It's not done yet. The Schreiber requests that we choose a number. Jup: We? Whom can we choose?

Gošer: I've proposed to the Schreiber that he picks a 'Muselmann'. Someone who is doomed anyway. He claims that all 'Muselmänner' have already been selected.

Kefalo: To hell with him! We'll invent a number, then!

Gošer: We can't. If the number is fake, they will discover the deception. ${ }^{65}$

They take a vote to decide which of them should die: with four against three (only later do they realize that Zelman did not vote), it is decided that Zelman Levental is to replace Gošer. This episode exemplifies what Langer calls 'choiceless choice'. According to Langer, time and again the logic of the extermination camps deprived the inmates of the freedom of moral choice, confronting them with situations of 'choiceless choice', 'where critical decisions did not reflect options between life and death but between one form of "abnormal" response and another, both imposed by a situation that was in no way of the victim's own choosing. ${ }^{66}$

Twenty years later, this event still profoundly divides the former inmates and they are tormented by the question of whether it was worth sacrificing Zelman Levental's life. While the religious Jew Šalom asks, 'Who has the

\footnotetext{
${ }^{65}$ Đorđe Lebović, Viktorija, Novi Sad, 1968, pp. 87-88. Further references to Viktorija will be given in the text.

${ }^{66}$ Lawrence Langer, 'The Dilemma of Choice in the Deathcamps', in Alan Rosenberg and Alan M. Myers (eds), Echoes from the Holocaust: Philosophical Reflections on a Dark Time, Philadelphia, PA, 1988, pp. 118-27 (p. 120).
} 
right to sacrifice the life of another, when nobody has the right to sacrifice himself', and 'What can you expect from life as long as you remember that you have taken away the life of someone else?' (pp. 90-91), Gošer defends himself against this implicit accusation:

Here [in the camp] I could have kept silent and looked after my own interests, but I organized sabotage: Edek perished, and you despise me all. What for? [...] What for? Who benefited from this? Did the war end earlier because of me? Was someone rescued because of me? (pp. 94-95)

Moreover, at the end of the trial it turns out that precisely the decision to sacrifice one of their own for the sake of the underground protest movement provoked Šalom, Zelman's closest friend, to tell Musfeld about the uprising, as a result of which Edek Jašonski was killed. At the end of the piece, Šalom reveals he was the one who informed Musfeld of the planned uprising, and breaks down:

I wanted to be an avenger, but became a traitor, I wanted to become a sacrifice, but was a braggart. [...] Edek!... Zelman!... (He approaches the monument, raises his hands in the air. He screams. It is a moan, a scream...)

(pp. 127-28)

His words from the trial, 'What can you expect from life as long as you remember that you have taken away the life of someone else?', now acquire an entirely different meaning: he survived the camp, but is burdened by his memories of it for the rest of his life. Rather than casting the survivors as heroes or fighters for a righteous cause (be it the socialist revolution or, as the prosecution at the Eichmann trial suggested, the creation of the future state of Israel), ${ }^{67}$ Viktorija seems to suggest that those who survive the camps are not necessarily heroes or virtuous people. Crucially, however, Viktorija reminds us that it is the reality of the camp that made it almost impossible to survive without compromising the moral values in which individuals believed before entering it. Rather, it shows us 'a series of personal histories beyond judgment and evaluation, 68 examples of what Langer calls the 'diminished self' of unheroic memory. ${ }^{69}$

In the case against Pendel, the key witnesses of the prosecution, Iris and Estera, provide contradictory accounts of the killing on Christmas

${ }^{67}$ See Lawrence Douglas, The Memory of Judgment: Making Law and History in the Trials of the Holocaust, New Haven, CT, 2001, pp. 153-73.

${ }^{68}$ Langer, Holocaust Testimonies, p. 183.

${ }^{69}$ Ibid., pp. 162-205. 
Eve 1943 of more than one hundred women who had been forced to work as prostitutes in the so-called 'House of Dolls'. According to Estera (at least, this is the version she presents in court), the women had organized an uprising which was violently suppressed by the German guards commanded by Pendel. Iris, however, insists that there had never been an uprising, but that Pendel's soldiers had committed a massacre. This episode seems to refer to a massacre at the women's camp in Budy, close to Auschwitz, committed in autumn of 1942, in which ninety unarmed female Jewish prisoners from France were brutally killed by their (German female) kapos, using truncheons, rifle butts and axes. During his interrogation in Krakow in 1946, Auschwitz commandant Rudolf Höss claimed that the German kapos of the Budy camp had crushed the prisoners' attempt at rebellion. Subsequent research, however, has shown that there had been no uprising or attempt to escape, but simply 'an unyielding life-and-death struggle waged by the Jewish women prisoners from France against their German tormentors who decided to slaughter them. ${ }^{70}$ In Viktorija, the prosecution quotes from 'the diary of Alojz Erdman, officer of the Political Section, who was present at the investigation in "The House of Dolls", on the first day of Christmas, at dawn' (pp. 79-80). The scene depicted in Viktorija closely resembles the report of the massacre written by Pery Broad, who as an official of the Political Section was part of the SS investigation team that inspected the Budy camp the morning after the massacre and whose version did not coincide with Höss's alleged crushing of an uprising. ${ }^{71}$

The Pendel case shows that the testifying survivors' need for a heroic (and thus morally and socially acceptable) narrative of resistance against their perpetrators may lead to their conscious or unconscious refashioning of the past. This need to refashion the past is undoubtedly caused by social pressure and the expectations of broader layers of society: nowhere did women who worked as prostitutes in the camp brothels fit the moral categories preferred by the dominant politics of memory. In the immediate post-war era, they not only could not speak freely about their fate, but most often were not even recognized as victims, and until recently their fate had been relegated to the periphery of Holocaust studies. ${ }^{72}$ By an ironic twist in the play, however, the survivors' need to establish a heroic narrative suits the needs of the perpetrator as well: Pendel is acquitted after Iris, the

\footnotetext{
70 Adam Rutkowski, 'An Attempted Uprising of the Jewish Women Prisoners in the Budy Camp?', Yad Vashem Studies, 18, 1987, p. 274.

${ }^{71}$ For a comparison of the accounts of both Höss and Broad, see ibid., pp. 265-66.

72 See Sonja M. Hedgepeth and Rochelle G. Saidel, 'Introduction', in Sonja M. Hedgepeth and Rochelle G. Saidel, Sexual Violence Against Jewish Women during the Holocaust, pp. $1-5$.
} 
only witness who had categorically stated that it was a massacre, changes her account of what happened and ultimately sides with Estera. As the private conversation between Iris and Estera reveals, there had never been an uprising:

Estera: You know very well that an uprising was impossible!

Iris: I know. My little dolls were not only filled with scraps, but also with fear...

Estera: Still, that's not important. What's important is only that the uprising in the 'House of Dolls' has entered legend.

Iris: Dear Estera, people don't need legends... (bursts into laughter): People don't need legends about brothels, but brothels!

Estera: You know very well who needs this legend!

Iris: Who does? The dolls? So where are they? If they are so in need of a legend, why didn't they show up? Why didn't they come to assert and defend their legend against a monster like Iris?

Estera: One is enough.

Iris: (ironically): You?

Estera: I.

Iris: OK. Defend it then... (p. 76)

Shame prevented the other girls from testifying against Pendel. The madeup story of the uprising in the brothel is proclaimed by the court to be the true version of the past. It credits the survivors with heroic behaviour and provides them with a version of the past that will boost their esteem in the eyes of non-survivors, but the real perpetrator goes free. Thus, the piece confirms Langer's point that 'the pretense that from the wreckage of mass murder we can salvage a tribute to the victory of the human spirit is a version of Holocaust reality more necessary than true'.73

Secondly, Viktorija points to the unbridgeable gap between the (legal) idiom and procedures used in court and the reality of the camps, and lays bare the impotence of the legal system and its reliance on criminal law to come to grips with the enormity of crimes committed during the Holocaust. For example, the judge insists that both the witnesses and the prosecution 'watch their language' when they talk about the camp brothel. Instead of 'whorehouse' or 'camp brothel', he prefers the expression 'Club for the Entertainment of the Soldiers', a euphemism also used by Pendel's defence lawyer (pp. 37, 39, 41), while Pendel himself even talks about 'female camp functionaries [logorašice-funkcionerke]' (p. 41) when

${ }^{73}$ Langer, Holocaust Testimonies, p. 165. 
referring to the women forced into prostitution. Such a derisory attitude towards the survivors and a profound unwillingness to understand their fate in the camps is reminiscent of the way in which the defence lawyers at the Frankfurt Auschwitz Trial tried to discredit the surviving witnesses. ${ }^{74}$ Moreover, as Devin Pendas notes, the perfunctory denazification of postwar German society made it possible that some of the defence lawyers at the Frankfurt Auschwitz Trials not only defended the legality of Nazi law, but even made antisemitic claims. ${ }^{75}$ In Viktorija, the belief in the continuing validity of Nazi law is blatantly obvious in the claims of the defendants and their lawyers. Musfeld's defence lawyer, for example, constantly insinuates that what the members of the Sonderkommando were doing (i.e., organizing an uprising) was illegal:

Defence Lawyer: Did you continue your activity [as leader of the resistance] in this camp?

Gošer: Yes, I did. Immediately upon my arrival I got in touch with the resistance movement in the camp.

Defence Lawyer: Was that movement legal?

(Gošer only smiles.)

Judge: Answer the question.

Gošer: No, it wasn't legal.

Defence Lawyer: So, you were breaking the law? (pp. 19-20)

Such a strain of argumentation clearly betrays a belief in the intrinsic legality of Nazi law, which in turn implies the cynical view that the things which occurred in the extermination camps were not actually crimes, so the defendants could not be found guilty of anything. Pendel's lawyer, for example, insists that his client 'only obeyed the military commands' and 'strictly stuck to orders' (p. 43). Lebović here clearly alludes to the Befehlsnotstand or defence of superior orders which, as Pendas notes, 'prove[d] central to the defense strategy in the Auschwitz Trial'? ${ }^{76}$

Such a view is, of course, also put forward by the defendants themselves, for example by Musfeld, who maintains: 'The SS was proclaimed a criminal organization after the war, sir' (p. 18, emphasis in the original - S.V.). Musfeld's claim that 'he was not acquainted with the practices of the SS', and that before his arrival in Auschwitz 'he had heard about [the concentration camps] but did not believe in those stories' (p. 199), echoes

${ }_{74}$ Devin O. Pendas, The Frankfurt Auschwitz Trial, 1963-1965, Cambridge, 2006, p. 162.

75 Ibid., pp. 220-26.

${ }^{76}$ Ibid., p. 33 . 
Robert Mulka's famous statement that at the time of his posting 'he did not know what Auschwitz was. ${ }^{77}$ Musfeld's answer to the judge's question as to whether he feels guilty - 'No, not in the sense of the indictment ${ }^{78}-$ echoes the notorious response, 'Nicht schuldig im Sinne der Anklage' ('Not guilty in the sense of the indictment'), frequently uttered by high-ranking SS officers at the Nuremberg Trial and by Eichmann himself at the trial in Jerusalem.

Musfeld's defence lawyer not only makes the actions of the camp inmates a matter of legal contention, but he openly questions the moral integrity of the survivors and their actions at the time, ascribing to the testifying survivors an agency which they clearly did not have in the camps. In his cross-examination of the witnesses, he cynically equates perpetrator and victim, asking Gošer exactly the same questions his client was asked by the prosecutor:

Defence lawyer (to Gošer): Sir, you told us that you were an eyewitness of the events that happened in the crematoria. Didn't you say so?

Gošer: Yes, I did.

Defence lawyer: And did you agree with such practices?

Gošer: No. No, I didn't.

Defence lawyer: You didn't? What did you undertake then against such practices? (p. 21)

Imputing to them that they 'chose' to kill a person (Zelman Levental) to save the life of another (Gošer), while Musfeld chose to kill one of them (Edek Jašonski) to save six lives, Musfeld's defence lawyer not only suggests that there is no difference between the crime of his client and the actions of the inmates, but that, if his client is prosecuted for this, the inmates should be put on trial too:

Defence lawyer: Your honour, these people sacrificed an innocent man to save one life. Musfeld sacrificed one man in order to save six lives. Nevertheless, he is being tried. For what? (p. 89)

In relation to the Frankfurt Auschwitz Trials, Pendas notes that due to the subjectivist foundations of German law, 'German courts could not

77 Quoted in ibid., p. 132.

78 This answer is only mentioned in the 2007 edition of Viktorija: Đorđe Lebović, Tetralogija, Belgrade, 2007, p. 199. In the 1968 edition, Musfeld's answer is, simply, 'Not entirely' (p. 18). 
adequately represent many of the most significant elements of the complex historical process of exterminating European Jewry'. What is more, 'guilt in German law assume[d] a direct causal link between free, subjective, individual decisions and behavioral outcomes in the world'79 As argued above, Viktorija shows that camp inmates were never able to make free individual decisions, which makes the contrast with the rules according to which their perpetrators were tried even greater.

Absurd claims such as the ones made by Musfeld's lawyer in the previously quoted passage were not only the fault of the political inclination of the defence lawyers who used the court to more or less openly voice their sympathies for Nazism, making the prosecution cry out, 'Who is being prosecuted here?' (p. 89). Rather, the play reveals that the court is seriously constrained by the operating logic and procedures of criminal law, which obfuscate (or refuse to take into account) the factors that had made possible in the first place such horrible things as extermination camps, a Sonderkommando and a camp brothel to exist. Viktorija shows that, as a consequence of this, the trial is not able to tackle seriously the crimes of Nazism. This could be illustrated by the misunderstanding that arises when the prosecutor asks Iris to describe how the massacre began:

Prosecution: [...] (addressing Iris)... Miss, I beg you to describe to us systematically what happened.

(Iris keeps silent.)

Prosecution: Well, how did everything start?

Iris: Everything started on Wednesday, at noon, when I sat next to my mother... and I was drawing the sea, a boat... Clouds... My brother opened the door and shouted: 'They're coming...' (pp. 115-16)

To the question, 'when did it start', Iris answers, 'it started when they came [to deport us to the camps]', indicating not only the difficulty for survivors in conveying their experience in the form of a linear narrative with a clear start and end point, but also the way in which the inner logic of a trial that draws on notions provided by criminal law does not allow for consideration of the broader historical, political, economic and sociological context of the rise and success of Nazism. The 'narratives presented to the court remain truncated and partial', ${ }^{80}$ therefore, making it all the more difficult to judge, let alone to achieve justice. After the confusion that follows Iris's answer,

79 Pendas, The Frankfurt Auschwitz Trial, pp. 53, 56.

${ }^{80}$ Douglas, The Memory of Judgment, p. 167. 
Iris firmly states that there had been an uprising, leading the court to the following absurd and cynical verdict:

Judge: The court has decided! (Reads.) Since it has been proved that in the night before Christmas, in the year 1943, in this concentration camp, in the 'Club for the Entertainment of the Military', a planned uprising of female inmates broke out, and since it has been proved that the guards reacted in accordance with the military regulations in force at the time, and that they used their weapons carrying out their duty, the court has decided that the former leader of the guards, Ludvig Klaus Pendel, is acquitted of the charges. (Bangs the gavel.) In the name of justice... (pp. 117-18)

Rather than showing the law as the instrument through which justice can be achieved, Viktorija seems to support Lawrence Douglas's point that 'the law is [not] adequate to the task of securing the history of the Holocaust in responsible memory', and that 'the efforts to use legal means to safeguard the history of the Holocaust may contribute to distortions of the very historical record that the law has been asked to defend'. ${ }^{81}$ The play not only reveals the constraints of a legal framework in dealing with traumatic memory, but also questions the possible impact of war crimes trials on the public awareness, understanding and memory of the Nazi genocide of the Jews. For the survivors there is no victory, no Judgement Day powerful enough to suspend the death of those killed in the Nazi extermination camps, or to resurrect them. This runs contrary to the words from Paul's First Epistle to the Corinthians - 'Where, o death, is your victory? Where, o death, is your sting?' ('Ubi est mors, Victoria tua? Ubi est mors, stimulus tuus?', 1 Corinthians, 15:55) - that concludes Krzysztof Penderecki's Dies irae: Auschwitz Oratorio with which the play ends. The people who perished in the concentration camps are not martyrs, their deaths make no sense and cannot (or may not) be recuperated or appropriated for any theological or political grand narrative.

In conclusion, Lebović's The Heavenly Squad and Viktorija articulate a series of complex ethical and aesthetic questions pertaining to the memory of the Holocaust and its artistic representation, questions which unsettle received notions of judgment and justice. Focusing on the fate of a Sonderkommando in Auschwitz-Birkenau, The Heavenly Squad not only introduces the specificity and enormity of the Holocaust to the larger public in Yugoslavia, it also draws our attention to the difficulty, or even

${ }^{81}$ Douglas, 'The Memory of Judgment: The Law, the Holocaust and Denial', p. 101. 
sheer impossibility of passing judgment on people caught in what Primo Levi termed 'the grey zone' of the concentration camp. Several years before the Eichmann trial, this play urges audiences to move away from a clearcut distinction between perpetrators and victims, revealing that notions of guilt and complicity are far more complex than usually assumed - in Socialist Yugoslavia as well as in many Western countries (for example, the USA, France and Israel) in the immediate post-war years. What is more, Lebović and Obrenović show that traditional notions of tragedy and catharsis do not work in the case of the Sonderkommando as an extreme example of the grey zone. Therefore, attempts to appropriate the play for a teleological historiographic narrative relying on the hero/martyr dichotomy are frustrated from the very beginning, which explains the negative reaction to the play by critics such as Bora Glišić.

Similarly, the play Viktorija contrasts the unheroic memory of camp survivors with notions of resistance and heroic behaviour often gratuitously assumed by non-survivor audiences. The survivors' experience of the camps does not fit the stereotypical scheme of heroic anti-fascist struggle, most importantly because the camp inmates were, as Lawrence Langer has pointed out, never in control of the consequences of their actions. Their memories resist closure - at times they cannot even be phrased in a linear narrative - which unavoidably brings them into conflict with the logic of the court. In addition, Viktorija reveals the blind spot of criminal law and the impotence of legal categories to get a grip on the reality of the extermination camps and to deal with the reality of genocide. While the need to prosecute the perpetrators is never questioned, the play ad absurdum shows how the possibility to deliver justice is frustrated by the limitations of the legal system within which the court operates. Most importantly, Viktorija points to the court's failure (following the logic of criminal prosecution) to take into account the broader historical context in which the Nazi genocide of European Jews had become possible. As a consequence, the trial proves to be too badly equipped to establish historical truth and thus to act as a reliable mediator of traumatic memory.

Both plays creatively and provocatively intervene in the dominant politics of remembrance of Socialist Yugoslavia, not by negating the 'brotherhood and unity' principle, but by hinting at the blind spots of its Manichean rhetoric and teleological narrative, and at its understanding of survivor testimony as 'historical evidence'. Furthermore, many of the pertinent issues relating to Holocaust remembrance and post-war justice tackled by the plays were not only typical of Socialist Yugoslav memory culture, but of the immediate post-war years in the West as well. 